\title{
Bahan Ajar Cerita Rakyat sebagai Perancah Pendidikan Karakter (Folklore Teaching Materials as a Character Education Scaffold)
}

\author{
Suherli Kusmana, ${ }^{\mathrm{a}, 1}$ dan Bela Nurzaman ${ }^{\mathrm{a}, 2}$ \\ ${ }^{a}$ Universitas Swadaya Gunung Jati, Cirebon, Indonesia \\ 1'suherli2@gmail.com; ${ }^{2}$ belanurzaman@gmail.com \\ Article info \\ Article history: \\ Received: 21-02-2021 \\ Revised : 18-04-2021 \\ Accepted: 10-05-2021

\section{A B S T R A C T} \\ This study aims to obtain folklore teaching materials as a \\ character education scaffold. The folklore studied was taken \\ from the environment of Cirebon community students. The \\ research method used is research and development. The stages \\ carried out are (1) initial collection and analysis of folklore, \\ textbooks used, and the need for teaching materials; (2) \\ development of teaching materials design and validation; (3) \\ reconstruction of teaching materials based on input from expert \\ validation results; (4) evaluation through the feasibility test for \\ use in learning in schools; and (5) implementation of teaching \\ materials in learning. The results showed that the development \\ of affective competence through folklore is a scaffold for \\ students' character education. The development of character \\ education is used to develop ideas or ideas in compiling short \\ stories. Character education is carried out through teaching \\ materials containing the values of local wisdom of folklore into \\ short stories.
}

Keywords:

development of teaching materials

folklore teaching materials scaffold for students'

character

Penelitian ini bertujuan untuk mendapatkan bahan ajar cerita rakyat sebagai perancah pendidikan karakter. Cerita rakyat yang diteliti diambil dari lingkungan peserta didik masyarakat Cirebon. Metode penelitian yang digunakan adalah penelitian dan pengembangan. Adapun tahapan yang dilakukan adalah: (1) pengumpulan dan analisis awal cerita rakyat, buku teks yang digunakan, dan kebutuhan bahan ajar; (2) pengembangan desain bahan ajar dan validasi; (3) rekonstruksi ulang bahan ajar berdasarkan masukan hasil validasi ahli; (4) evaluasi melalui uji kelayakan penggunaan dalam pembelajaran di sekolah; dan (5) implementasi bahan ajar dalam pembelajaran. Hasil penelitian menunjukkan bahwa pengembangan kompetensi afektif melalui cerita rakyat merupakan perancah (scaffolding) bagi pendidikan karakter siswa. Pengembangan pendidikan karakter dimanfaatkan untuk mengembangkan ide atau gagasan dalam menyusun cerita pendek. Pendidikan karakter dilakukan melalui bahan ajar bermuatan nilai-nilai kearifan lokal cerita rakyat ke dalam cerita pendek.

Copyright (C) 2021 Institut Agama Islam Negeri Syekh Nurjati Cirebon. All rights reserved

\section{PENDAHULUAN}

Bahan ajar teks cerita rakyat banyak ditemukan di sekitar lingkungan siswa, baik yang sudah dicetak maupun masih berupa sastra lisan yang berhubungan 
dengan nama suatu daerah. Dalam pengembangan kognitif siswa, jika cerita rakyat yang menjadi bahan ajar itu berhubungan dengan nama suatu daerah di sekitar tempat tinggal siswa akan dapat meningkatkan pemahaman siswa (Oring, 2008). Dalam pengembangan kemampuan psikomotorik, tidak mungkin di akhir pelajaran siswa mengembangkan cerita rakyat namun yang paling memungkinkan adalah mengembangkan ide atau gagasan dari cerita rakyat tersebut sebagai inspirasi yang dapat dikembangkan ke dalam suatu cerita pendek. Dengan demikian, pengembangan kreativitas siswa dapat terbangun melalui pengembangan sikap dengan melatih siswa mengimplementasikan nilai-nilai kearifan lokal suatu cerita rakyat ke dalam cerita pendek yang dibuatnya (Kusmana \& Jaja, 2019).

Bahan ajar yang mengajarkan nilai-nilai moral dapat digali dari kearifan lokal suatu masyarakat. Kearifan lokal tersebut dapat diperoleh dari cerita rakyat. Nilainilai moral tersebut dapat diwariskan melalui pendidikan dalam bentuk pendidikan karakter (Balitbang, 2010). Karakter sebagai akhlak mulia atau moral excellence dibangun di atas berbagai kebajikan (virtues) yang pada gilirannya hanya memiliki makna ketika dilandasi oleh nilai-nilai yang berlaku dalam budaya suatu bangsa. Karakter bangsa Indonesia adalah karakter yang dimiliki warga negara Indonesia berdasarkan tindakan-tindakan yang dinilai sebagai suatu kebajikan berdasarkan nilai yang berlaku di masyarakat. Nilai-nilai yang berlaku dalam budaya sebagai kearifan lokal, yang dapat diperoleh dari cerita rakyat sebagai salah satu warisan budaya (Oring, 2008; Finnegan, 2018). Nilai-nilai warisan budaya tersebut dapat dikembangkan sebagai bahan ajar, karena pengembangan bahan ajar yang relatif baru sedang banyak dilakukan, termasuk yang digali dari lapangan dan lingkungan (Tolimson, 2012; Du Toit, 2014).

Bahan ajar harus berisi informasi materi pelajaran, mempermudah siswa dalam mempelajari materi, mampu memenuhi kebutuhan peserta didik, bersifat lengkap, sehingga siswa tidak perlu mencari dan menggunakan bahan ajar lainnya, serta bahan ajar tersebut mengikuti perkembangan teknologi dan mudah dipakai (Murray \& Goldbart, 2009). Dengan demikian setiap materi, baik instruksi dan paparan informasi; penyajian; penggunaan bahasa; dan grafika penulisannya bersifat membantu dan bersahabat dengan pemakainya. Bahan ajar mengacu pada pemenuhan empat komponen yaitu isi atau materi, sistematika penyajian, bahasa, dan grafika atau tampilan (Kusmana, 2014). Komponen tersebut menjadi penentu kualitas suatu buku yang digunakan sebagai bahan ajar. Oleh karena itu, kelayakan bahan ajar dapat ditentukan berdasarkan aspek-aspek dari keempat komponen tersebut.

Cerita rakyat merupakan tradisi lisan yang pada umumnya secara turuntemurun diwariskan kepada masyarakat, seperti dongeng Sangkuriang, Si Kabayan, dan lain sebagainya. Penyebaran cerita rakyat dilakukan secara lisan sehingga tidak diketahui penulisnya atau anonim, namun akhir-akhir ini sudah ada upaya mendokumentasikan dalam bentuk teks tertulis. Cerita rakyat juga berbentuk tuturan yang berfungsi sebagai media pengungkapan perilaku tentang nilai-nilai kehidupan yang melekat di dalam kehidupan masyarakat. Cerita rakyat adalah bagian dari folklor (Danandjaya, 1994). Cerita rakyat digunakan sebagai petuah orang tua kepada generasi penerus untuk memahami, menghargai, sampai dengan meneladani nilai-nilai dari perilaku dan karakter tokoh, dialog, dan latar cerita yang memiliki nilai kebaikan. Pewarisan nilai-nilai moral tersebut dilakukan sebagai 
tradisi dari suatu masyarakat yang ingin mempertahankan karakter bangsanya kepada generasi berikutnya.

Cerita rakyat itu merupakan salah satu warisan budaya yang berkembang dan hidup di lingkungan masyarakat. Jenis-jenis cerita rakyat terdiri atas tiga golongan besar, yaitu: (1) mite (myth), (2) legenda (legend), dan (3) dongeng (folktale) (Danandjaja, 1994). Cerita rakyat sebagai sebuah karya sastra memiliki pesan moral bagi pembacanya sehingga sangat baik apabila diterapkan dalam pembelajaran kepada siswa. Dari pembelajaran ini, selain siswa dapat lebih mengenal kearifan lokal di daerahnya, pengembangan bahan ajar yang digali dari nilai-nilai moral cerita rakyat sebagai kearifan lokal suatu daerah akan sangat bermanfaat bagi peserta didik dalam mengaitkan materi ajar berdasarkan konteks sosial masyarakat (Balitbang, 2010). Cerita rakyat dapat dikaji strukturnya sehingga dapat digunakan sebagai bahan ajar yang memiliki nilai-nilai positif dan memberi banyak manfaat kepada peserta didik (Kusmana \& Jaja, 2019; Liendo, 2017). Nilai-nilai yang terkandung di dalam cerita rakyat perlu dipelihara dan diwariskan kepada generasi penerus. Sebagai warisan atau peninggalan nenek moyang, kearifan lokal merupakan kekayaan budaya dan tradisi besar yang tidak hanya harus dipertahankan atau dilestarikan, tetapi juga harus diterapkan dalam kehidupan sehari-hari.

Pendidikan karakter merupakan salah satu upaya dalam menanamkan nilainilai jati diri bangsa kepada peserta didik yang meliputi afektif, kognitif, dan psikomotorik. Dari komponen tersebut diharapkan timbul pemahaman, tindakan, kesadaran, dan kemauan untuk melaksanakan atau mewujudkan nilai-nilai tersebut dalam kehidupannya. Dalam melaksanakan pendidikan karakter di sekolah, semua aspek harus dioptimalkan, seperti isi kurikulum, proses pembelajaran dan penilaian, penanganan atau pengelolaan mata pelajaran, pengelolaan sekolah, pelaksanaan aktivitas kokurikuler dan ektra kurikuler, pemberdayaan sarana prasarana, pembiayaan, dan etos kerja seluruh warga sekolah atau lingkungan (Hermawati, 2010). Hal ini berarti bahwa pendidikan karakter dapat diinternalisasikan melalui komponen isi kurikulum berupa penyediaan perangkat pembelajaran yang salah satunya adalah bahan ajar. Dengan demikian, dalam melaksanakan pendidikan karakter bahan ajar harus dioptimalkan untuk menginternalisasi nilai-nilai moral dalam diri siswa yang dapat diaktualisasikan dalam bentuk aktivitas berkreasi secara lisan maupun tulisan.

Kenyataan yang sering dialami, pendidikan karakter merupakan bagian dari lingkungan sekolah yang dapat membantu siswa dalam perkembangan etika, model pertanggungjawaban, dan partisipasi karakter yang baik melalui nilai-nilai universal (Berkowitz \& Bier, 2005). Nilai-nilai universal tersebut akan dapat terbentuk dalam kejiwaan seseorang. Karakter itu berhubungan dengan wilayah psikologis seseorang, sehingga berhubungan dengan aspek perilaku, sikap, cara pandang, dan kualitas yang membedakan satu orang dengan orang lain yang dapat membuat seseorang menjadi lebih luar biasa daripada orang lain (Rokhman et al., 2014). Nilai-nilai karakter bangsa Indonesia perlu ditanamkan kepada para siswa sehingga mereka mampu menerapkan dalam kehidupannya, baik di keluarga, sekolah, masyarakat, dan negara agar dapat memberikan kontribusi yang positif kepada lingkungannya. Karakter adalah bagian dari elemen spesifik manusia yang mencakup kemampuan mereka menghadapi tantangan dan kesulitan (Kemko Kesra 
2010). Karakter diartikan sebagai tabiat, sifat-sifat kejiwaan, akhlak atau budi pekerti yang membedakan seseorang dengan yang lain.

Pada dasarnya pendidikan karakter dapat dimulai dari lingkungan keluarga terlebih dahulu sebagai tahap awal seorang anak mengenal lingkungannya untuk bertindak sesuai dengan nilai-nilai kebaikan dan norma yang seharusnya dilakukan (Kamil, 2015). Menurut pendukung pendidikan karakter tradisional, membaca cerita kebajikan merupakan salah satu pilar pendidikan moral (Narvaez, 2002). Oleh sebab itu melalui sastra yang hebat dan memiliki muatan nilai-nilai moral dapat menciptakan empati dan nilai-nilai bersama, serta mampu menunjukkan sifat karakter moral dan tidak bermoral (Honig, 1985). Pembentukan karakter melalui pendidikan karakter di sekolah terdapat 18 jenis karakter yang harus dipahami dan diimplementasikan, yaitu religius, jujur, toleransi, disiplin, kerja keras, kreatif, mandiri, demokratis, rasa ingin tahu, semangat kebangsaan, cinta tanah air, menghargai prestasi, komunikatif, cinta damai, gemar membaca, peduli lingkungan, peduli sosial dan tanggung jawab (Suyadi, 2013). Dengan demikian, bahan ajar yang berisi kisah-kisah kebajikan yang menginspirasi dalam suatu cerita atau dalam teks-teks yang berisi motivasi dan aspirasi para tokoh inspiratif atau pahlawan moral yang menghadapi berbagai konflik dalam kehidupan merupakan kisah yang sangat penting dalam pembentukan karakter. Dengan membaca teks sastra atau teks-teks inspiratif maka anak-anak dapat belajar mengenai nilai moral tradisional dan menemukan sosok pahlawan atau tokoh yang akan ditirunya dalam kehidupan. Teks sastra atau teks inspiratif tersebut dapat digunakan sebagai bahan pembelajaran.

Perancah (scaffolding) pada awalnya merupakan istilah yang digunakan untuk alat bantu bagi seseorang dalam mengkonstruksi suatu bangunan atau suatu konstruksi. Istilah ini kemudian berkembang dalam pembelajaran sebagai analogi seorang guru yang mengkonstruksi kemampuan seseorang dalam belajar dengan berbagai upaya dalam mencapai tujuan. Upaya yang ditempuh guru menggunakan model, strategi, bahan ajar, dan media yang dijadikan perancah berdasarkan Zone of Proximal Development (ZPD) siswa. Berdasarkan teori belajar sosial Vygotsky dikatakan bahwa belajar akan terjadi dalam suatu konteks sosial percakapan dan keterampilan berpikir yang hanya dapat terjadi melampaui Zone of Actual Development (ZAD) siswa. Dengan demikian, proses belajar siswa akan terjadi dalam konteks pengembangan ZPD siswa yang dilakukan secara kolaborasi interaktif dengan guru sehingga kemampuan siswa akan meningkat dengan bimbingan dan bantuan guru melalui perancah (scaffolding). Istilah perancah ini kemudian berkembang menjadi suatu strategi pembelajaran yang diterapkan oleh guru dalam memberikan layanan siswa sesuai dengan kemampuan mereka yang beragam.

Perancah yang digunakan sebagai strategi pembelajaran dapat meningkatkan hasil pembelajaran yang dilakukan siswa. Kesulitan siswa dalam memahami atau menguasai suatu materi dapat terbantu dengan strategi scaffolding yang digunakan guru. Dengan demikian strategi pembelajaran scaffolding dirancang untuk mengatasi kesulitan siswa dalam memahami materi sesuai kemampuannya sehingga dapat meningkatkan pemahaman siswa tentang materi yang disajikan oleh guru (Kusworo \& Hardinto, 2009). Strategi pembelajaran yang digunakan menerapkan tahap-tahap yang digunakan dalam pendekatan genre pedagogik dengan menerapkan siklus Rhotery dalam pembelajaran. Pendekatan genre 
pedagogik didasarkan pada siklus belajar-mengajar "belajar melalui bimbingan dan interaksi" yang mengutamakan strategi pemodelan untuk dianalisis siswa, kemudian siswa membangun teks secara bersama-sama (joint construction) dengan bantuan guru, sebelum mereka membuat teks secara mandiri. Siklus yang dikembangkan Rothery mencakup: (1) pemodelan teks (modelling a text), (2) konstruksi terbimbing (joint construction of a text), dan konstruksi mandiri (independent construction of a text). Oleh karena itu, implementasi strategi ini menerapkan langkah-langkah penentuan Zone of Proximal Development untuk masing-masing siswa, kemudian siswa dikelompokkan berdasarkan tingkat ZPDnya dengan melihat hasil belajar sebelumnya (Mamin, 2008). Berdasarkan siklus pembelajaran genre pedagogik yang dikemukakan Rhotery ini maka pada tahap konstruksi terbimbing (joint construction of a text) ini diperlukan kehadiran guru untuk mengembangkan ZPD siswa. Pada pengembangan kemampuan ini diperlukan perancah agar terjadi proses belajar.

Sehubungan dengan hal tersebut, pendidikan karakter yang telah dimulai dari lingkungan keluarga, dapat mulai dikembangkan dalam konteks yang lebih luas ketika siswa belajar di sekolah. Siswa mempelajari 18 karakter positif sebagai proses pendidikan karakter dapat dilakukan dengan bantuan guru melalui perancah (scaffolding) bahan ajar yang mengusung nilai-nilai tersebut. Cerita rakyat memiliki nilai-nilai moral sebagai kearifan lokal dapat dianalisis dari nilai-nilai sastra sebagai pembangunnya (Finnegan, 2018). Pesan moral dari suatu cerita rakyat dapat dikembangkan ke dalam bahan ajar untuk pelajaran Bahasa Indonesia di Sekolah Menengah Atas. Berdasarkan studi pendahuluan diketahui bahwa di Kabupaten Cirebon terdapat banyak cerita rakyat yang merupakan salah satu budaya masyarakat yang dapat digunakan sebagai bahan pembelajaran di satuan pendidikan.

\section{METODE}

Metode penelitian yang digunakan adalah penelitian dan pengembangan sebagaimana yang dikembangkan Borg dan Gall (1983). Dari penelitian ini dihasilkan produk bahan ajar yang valid dan efektif (Sukmadinata, 2010) untuk digunakan dalam pembelajaran. Prosedur penelitian yang ditempuh meliputi tahap penelitian yang terdiri atas analisis kebutuhan bahan ajar, analisis standar kompetensi, mengumpulkan dan menganalisis cerita rakyat yang memiliki nilainilai moral, pengembangan bahan ajar, validasi bahan ajar cerita rakyat, dan uji coba bahan ajar. Selanjutnya tahap pengembangan terdiri dari pengembangan materi bahan ajar, validasi dan revisi bahan ajar cerita rakyat yang memiliki kearifan lokal (Sukmadinata, 2010; Sugiyono, 2010). Terakhir, tahap evaluasi bahan ajar cerita rakyat yang memiliki kearifan lokal berdasarkan uji kelayakan kepada para pengguna bahan ajar tersebut dalam pembelajaran. Adapun tahapan yang dilakukan adalah: (1) tahap analisis awal cerita rakyat, analisis buku teks yang digunakan, dan kebutuhan bahan ajar; (2) tahap mengembangkan desain bahan ajar dan validasi; (3) tahap rekonstruksi ulang bahan jaar berdasarkan masukan hasil validasi ahli dan praktisi; (4) tahap tes dan evaluasi atau uji kelayakan bahan ajar oleh pengguna, dan (5) tahap implementasi bahan ajar dengan ruang lingkup yang lebih luas.

Berdasarkan hal tersebut, maka penelitian yang dilaksanakan sejak Januari 2020 sampai dengan Juli 2021 melakukan tahapan yang dibagi ke dalam dua 
periode. Pada periode tahun pertama, dilakukan: (1) tahap analisis awal cerita rakyat, analisis buku teks yang digunakan, dan kebutuhan bahan ajar; (2) tahap mengembangkan desain purwarupa bahan ajar dan validasi; (3) tahap rekonstruksi ulang bahan ajar berdasarkan masukan hasil validasi ahli dan praktisi. Pada periode tahun kedua, dilakukan tahap evaluasi atau uji kelayakan bahan ajar oleh pengguna, baik siswa maupun guru Bahasa Indonesia. Namun, tahap implementasi bahan ajar dengan ruang lingkup yang lebih luas pada penelitian ini diintegrasikan dengan tahap uji kelayakan, karena semua sekolah sedang melaksanakan "belajar dari rumah" sehingga pembelajaran dilaksanakan secara daring. Bahan ajar yang dikembangkan dimodifikasi secara digital agar dapat disajikan secara virtual dalam pembelajaran daring. Tahap uji coba oleh para pengguna yang dilaksanakan secara daring membutuhkan durasi waktu yang cukup lama karena tidak semua sampel penelitian dapat dengan segera memberikan jawaban sebagaimana yang direncanakan dalam rancangan penelitian. Keterbatasan uji kelayakan dan wawancara secara tatap muka diatasi dengan menggunakan aplikasi Zoom Cloud Meeting dan aplikasi media komunikasi melalui telefon pintar.

Subjek penelitian ini terdapat dua jenis, yaitu subjek penelitian pada tahap analisis ketersediaan dan kondisi cerita rakyat terpilih di Kabupaten Cirebon serta analisis kebutuhan terhadap bahan ajar cerita rakyat yang memiliki kearifan lokal sebagai pendidikan karakter. Oleh karena itu, subjek dalam penelitian yang digunakan adalah dokumen naskah cerita rakyat dan para narasumber sastra lisan di Kabupaten Cirebon. Sementara itu, subjek penelitian pada saat melakukan validasi produk melalui menilai prototipe bahan ajar cerita rakyat adalah akademisi dan praktisi pendidikan bahasa Indonesia. Selanjutnya, subjek penelitian dalam melakukan ujicoba purwarupa bahan ajar adalah siswa SMA Negeri 2 Cirebon, siswa MAN 2 Cirebon, Siswa SMKN 7 Cirebon yang mengikuti pembelajaran secara daring dan para guru sebagai pengguna. Dari setiap sampel sekolah ditetapkan sepuluh orang siswa dari kelas $\mathrm{X}$ yang sedang mempelajari teks cerita rakyat. Selain itu, dari ketiga sekolah sampel tersebut dipilih guru-guru yang mengajarkan pelajaran Bahasa Indonesia yang digunakan sebagai nara sumber dalam pengukuran kelayakan bahan ajar sebagai perancah dalam pembelajaran.

Instrumen dalam penelitian ini adalah wawancara yang digunakan untuk menggali permasalahan pembelajaran di sekolah, pedoman analisis untuk menganalisis nilai-nilai kearifan lokal dalam cerita rakyat, pedoman validasi bahan ajar untuk mengukur validitas bahan ajar, dan angket yang digunakan untuk mengukur kelayakan purwarupa bahan ajar digunakan dalam pembelajaran. Data yang terkumpul dari hasil wawancara dianalisis untuk mendapatkan sintesis tentang pembelajaran, sedangkan data hasil analisis cerita rakyat digunakan sebagai titik tolak pengembangan bahan ajar cerita rakyat. Data hasil uji pakai bahan ajar untuk mengukur kelayakan bahan ajar digunakan dalam pembelajaran.

\section{HASIL DAN PEMBAHASAN}

Berdasarkan analisis terhadap cerita rakyat yang terkumpul diketahui bahwa cerita rakyat memiliki kesesuaian dengan struktur sastra sehingga dapat digunakan sebagai bahan pembelajaran kepada siswa. Dari analisis unsur pembangun sastra, cerita rakyat dari Cirebon dinyatakan memiliki nilai-nilai moral sebagai pesan yang termuat dalam cerita tersebut. Adapun cerita rakyat yang memiliki nilai-nilai moral itu sebagaimana tertuang dalam tabel 1 . 
Nilai-nilai moral yang terdapat dalam cerita rakyat sebagai mana dalam tabel di atas dapat digunakan sebagai contoh atau teladan bagi peserta didik. Nilai-nilai moral tersebut dapat digunakan sebagai materi pembelajaran pendidikan karakter. Selain itu, pembelajaran cerita rakyat bagi siswa akan memudahkan dalam mengenal latar dari suatu cerita terutama yang berhubungan dengan latar dan namanama tempat. Demikian pula dengan penokohan dalam cerita rakyat yang menggunakan nama-nama tokoh yang pada umumnya dikenal oleh para siswa sehingga bagi mereka cerita tersebut tidak sekedar cerita fiksi tetapi berhubungan dengan kehidupan masyarakat yang dikenalnya. Demikian pula dengan alur dan tema yang saling melengkapi dalam menyajikan gagasan yang memiliki nilai-nilai moral sebagai kearifan lokal.

Tabel 1.

Hasil Analisis Nilai-nilai Moral Cerita Rakyat di Kabupaten Cirebon

\begin{tabular}{|c|c|c|}
\hline No. & Judul Cerita Rakyat & Nilai-Nilai Moral \\
\hline 1 & Nyi Mas Gandasari & $\begin{array}{l}\text { Setiap manusia harus patuh dan taat pada } \\
\text { aturan, baik aturan Tuhan maupun aturan } \\
\text { manusia }\end{array}$ \\
\hline 2 & Mbah Kuwu Sangkan & $\begin{array}{l}\text { Setiap orang harus memiliki niat untuk } \\
\text { sukses dalam menggapai cita-cita. }\end{array}$ \\
\hline 3 & $\begin{array}{l}\text { Masjid Agung Sang Cipta } \\
\text { Rasa }\end{array}$ & $\begin{array}{l}\text { Sebagai manusia dengan kedudukan apapun } \\
\text { di hadapan Allah semua sama, karena yang } \\
\text { membedakan adalah nilai ketaqwaannya. }\end{array}$ \\
\hline 4 & Baridin dan Ratminah & $\begin{array}{l}\text { Bersikap sabar dan tawakal dalam } \\
\text { menghadapi ujian yang menimpa, karena } \\
\text { cinta tidak bisa dipaksakan dan sudah } \\
\text { ditetapkan bahwa manusia hidup berpasang- } \\
\text { pasangan. }\end{array}$ \\
\hline 5 & Sejarah Situs Mari Kangen & $\begin{array}{l}\text { Setiap orang harus yakin dan percaya hanya } \\
\text { kepada kekuasaan Allah. }\end{array}$ \\
\hline 6 & $\begin{array}{l}\text { Misteri Patung Perawan } \\
\text { Sunti }\end{array}$ & $\begin{array}{l}\text { Dalam menjalani kehidupan itu menjaga } \\
\text { tingkah laku supaya tidak melakukan } \\
\text { kesalahan. }\end{array}$ \\
\hline 7 & $\begin{array}{l}\text { Sejarah } \\
\text { Bayi }\end{array}$ & $\begin{array}{l}\text { Setiap orang harus dapat menjaga perilaku } \\
\text { agar tidak melakukan kesalahan karena hawa } \\
\text { nafsu. }\end{array}$ \\
\hline
\end{tabular}

Nilai-nilai moral yang terdapat dalam cerita rakyat sebagai mana dalam tabel di atas dapat digunakan sebagai contoh atau teladan bagi peserta didik. Nilai-nilai moral tersebut dapat digunakan sebagai materi pembelajaran pendidikan karakter. Selain itu, pembelajaran cerita rakyat bagi siswa akan memudahkan dalam mengenal latar dari suatu cerita terutama yang berhubungan dengan latar dan namanama tempat. Demikian pula dengan penokohan dalam cerita rakyat yang menggunakan nama-nama tokoh yang pada umumnya dikenal oleh para siswa sehingga bagi mereka cerita tersebut tidak sekadar cerita fiksi, tetapi berhubungan dengan kehidupan masyarakat yang dikenalnya. Demikian pula dengan alur dan tema yang saling melengkapi dalam menyajikan gagasan yang memiliki nilai-nilai moral sebagai kearifan lokal. 
Dari analisis kompetensi dasar dalam kurikulum dapat dikembangkan bahan ajar teks cerita rakyat yang disesuaikan dengan kompetensi dasar dalam kurikulum dan dihubungkan dengan pendidikan karakter yang menyajikan nilai-nilai kearifan lokal. Pengembangan kompetensi dasar dimulai dari pengembangan kognitif, kemudian dilakukan pengembangan psikomotorik. Setiap pengembangan kompetensi diarahkan pada kemampuan berbahasa secara tertulis dan lisan. Pengembangan kompetensi tersebut menggunakan bahan ajar sebagai perancah pendidikan karakter dalam pembelajaran. Adapun pengembangan desain bahan ajar teks cerita rakyat untuk siswa SMA, MA, dan SMK disusun sebagaimana peta konsep pada Gambar 1.

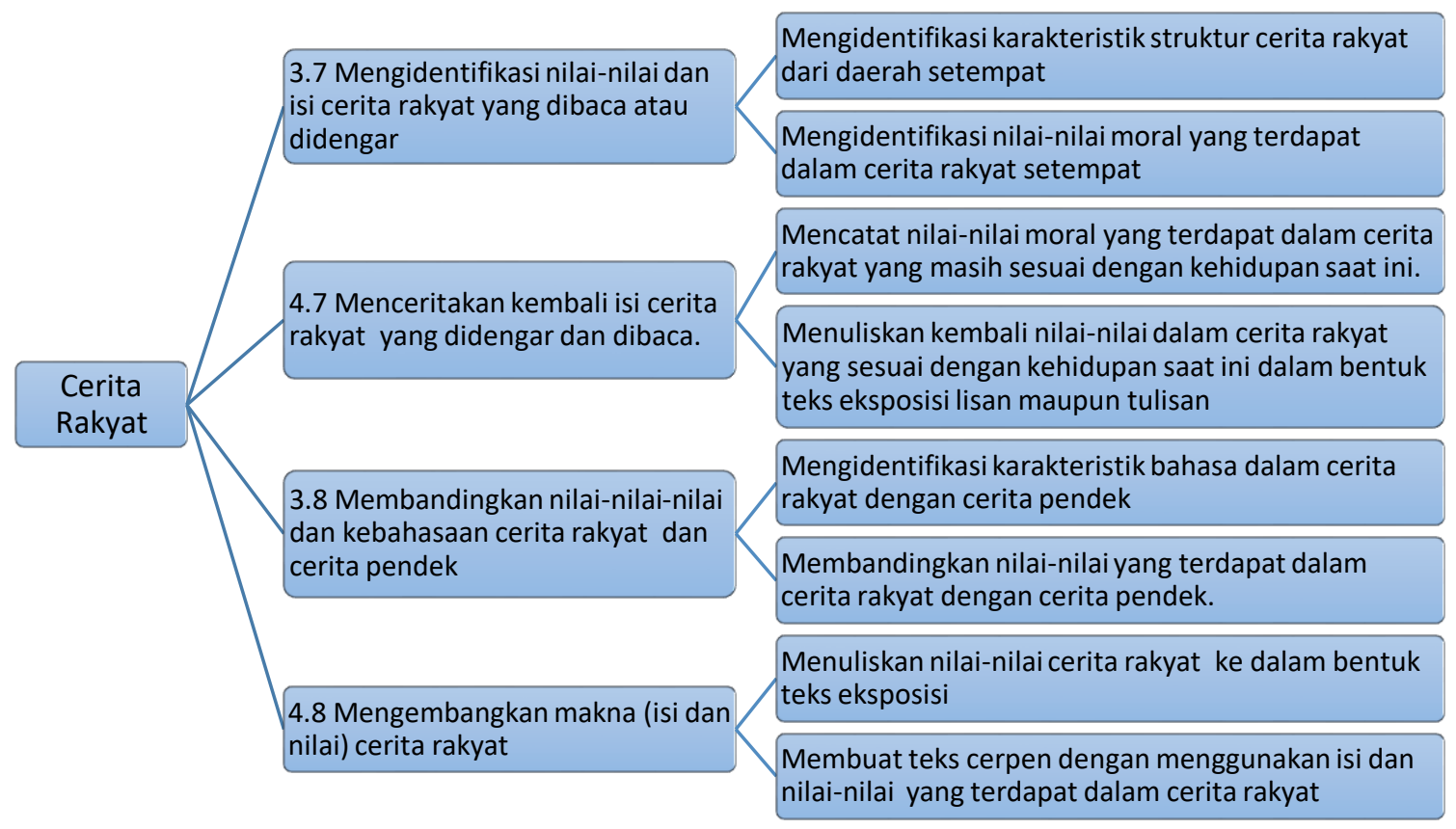

\section{Gambar1. \\ Peta Konsep Bahan Ajar Teks Cerita Rakyat Bermuatan Pendidikan Karakter}

Bahan ajar yang dikembangkan ini selanjutnya divalidasi oleh ahli dan praktisi. Komponen yang digunakan untuk memvalidasi bahan ajar adalah materi atau isi, penyajian, bahasa, dan grafika. Jumlah skor yang dikali bobot dari seluruh komponen tersebut maksimal 100. Dari pengukuran validasi yang dilakukan pakar atau akademisi mencapai skor 335,77 sehingga skor rata-rata dari semua komponen mencapai 83,94. Dengan demikian bahan ajar yang dikembangkan termasuk ke dalam kategori sebagai bahan ajar yang memiliki validitas tinggi.

Berdasarkan hasil uji pakai bahan ajar cerita rakyat bermuatan kearifan lokal di SMA, MA, dan SMK secara daring dan para guru pengguna diketahui bahwa bahan ajar cerita rakyat yang digali dari lingkungan masyarakat setempat dengan tempat tinggal siswa dapat meningkatkan pemahaman hasil pembelajaran. Berdasarkan uji kelayakan bahan ajar cerita rakyat sebagai perancah pendidikan karakter mencapai nilai rata-rata sebesar 84,01 dari lima aspek yang diukur. Berdasarkan hal ini maka dapat dinyatakan bahwa bahan ajar yang dikembangkan 
dari cerita rakyat masyarakat Cirebon memiliki kelayakan untuk digunakan dalam pembelajaran bahasa Indonesia di SMA, MA, atau SMK. Gagasan tentang pesan moral yang terdapat dalam cerita rakyat dapat dikembangkan ke dalam bentuk cerita pendek, ketika para siswa dilatih mengembangkan kemampuan kreativitasnya dalam berekspresi sastra secara tulis. Selain itu, para siswa juga dapat mengembangkan ide dari cerita rakyat ke dalam bentuk teks eksposisi. Para siswa dapat menyajikan gagasan dalam bentuk eksposisi yang bermuatan nilai-nilai moral dari cerita rakyat yang dibacanya.

Berdasarkan uraian hasil analisis terhadap cerita rakyat yang dapat dikumpulkan dari lingkungan masyarakat, maka dapat dinyatakan bahwa cerita rakyat yang berkembang di masyarakat Cirebon masih dapat diwariskan kepada generasi akan datang. Data yang diperoleh dari buku kumpulan cerita dan dari hasil wawancara tokoh-tokoh masyarakat dapat dipilah berdasarkan kelengkapan struktur sastra sebagai pembangun cerita. Cerita rakyat yang memiliki kelengkapan struktur terdapat nilai-nilai moral yang dapat diperoleh dari karakter tokoh yang terdapat dalam suatu cerita, baik dari dialog yang dilakukan maupun dari latar dan alur cerita. Dari struktur sastra secara lengkap tersebut dapat ditemukan nilai-nilai moral yang terdapat di dalamnya. Nilai-nilai moral tersebut masih relevan dengan nilai-nilai baik yang terdapat dalam kehidupan saat ini untuk dapat diteladani.

Penggunaan unsur kebahasaan masih dapat dipahami oleh pembaca saat ini, hanya ada beberapa kosakata yang ada dalam cerita rakyat tertulis yang pengertiannya harus didasarkan pada konteks kalimat. Hal ini berbeda dengan cerita rakyat yang disampaikan secara lisan oleh tokoh masyarakat. Karena menceritakan kembali cerita lisan yang pernah didengar dari orang tua, maka lebih mudah dalam menceritakan kembali dengan menggunakan bahasa yang mudah dipahami (Dąbrowska, 2019).

Purwarupa bahan ajar cerita rakyat yang disusun telah sesuai dengan kebutuhan siswa dan guru dan memiliki efektivitas yang tinggi. Berdasarkan komponen hasil validasi yang dilakukan oleh ahli dan praktisi (sebagaimana terdapat dalam tabel 2) bahan ajar yang dikembangkan memiliki validitas tinggi. Bahan ajar yang dikembangkan, selain dapat mengajari siswa untuk memiliki kemampuan literasi fiksi dalam membaca yang dilakukannya dan kemampuan berekspresi sastra, para siswa juga dapat memperoleh dampak pengiring (nurturant effect) dari cerita rakyat tersebut berupa pendidikan karakter.

Tabel 2.

Skor Hasil Validasi Bahan Ajar

\begin{tabular}{clc}
\hline No. & Komponen & Rerata Skor \\
\hline 1 & Materi/Isi & 81,55 \\
2 & Penyajian & 80,42 \\
3 & Bahasa & 85,35 \\
4 & Grafika & 88,45 \\
& Total & 335,77 \\
& Rata-rata & $\mathbf{8 3 , 9 4}$
\end{tabular}

Keterangan: memenuhi kriteria validitas tinggi 
Bahan ajar cerita rakyat yang dikembangkan memiliki kelayakan sebagai bahan ajar yang digali dari lingkungan masyarakat sekitar siswa sehingga lebih meningkatkan keefektifan pencapaian tujuan pembelajaran. Hal ini senada dengan penelitian Saputro (2017). Dengan demikian, analisis kebutuhan siswa dan guru dalam menyiapkan bahan ajar dapat dipenuhi dari penyediaan bahan ajar yang bersumber dari cerita rakyat yang ada di lingkungan siswa. Penggunaan latar tempat dan penokohan dalam cerita rakyat dapat memotivasi siswa untuk belajar maksimal dalam mewujudkan pencapaian kompetensi dasar.

Bahan ajar cerita rakyat yang dikembangkan dari lingkungan siswa lebih memudahkan siswa dalam memahami latar dan penokohan sehingga jalan cerita dan tema dari cerita rakyat tersebut mudah dipahami siswa. Jika cerita rakyat tersebut mudah dipahami maka minat siswa untuk belajar pun akan meningkat. Berdasarkan validasi dari ahli materi dan guru sebagai praktisi pembelajaran yang meninjau bahan ajar dari kelayakan materi atau isi, penyajian, bahasa, dan grafika menunjukkan bahwa bahan ajar itu harus memiliki kebenaran materi dan kesesuaian konsep.

Bahan ajar cerita rakyat yang memiliki pesan berupa nilai-nilai moral dapat digunakan sebagai perancah dalam pendidikan karakter kepada siswa. Pengecualian domain afektif dalam pembelajaran Bahasa Indonesia pada jenjang pendidikan dasar dan menengah dapat diatasi dengan muatan nilai-nilai moral sebagai pendidikan karakter, sebagaimana tertuang dalam tabel berikut:

Tabel 3.

Skor Hasil Uji Kelayakan Bahan Ajar sebagai Perancah

\begin{tabular}{|c|c|c|}
\hline No. & Aspek & Rerata Skor \\
\hline 1 & $\begin{array}{l}\text { Efektivitas penyajian pesan moral yang dipahami dari } \\
\text { cerita rakyat }\end{array}$ & 85,65 \\
\hline 2 & Kemampuan menyajikan dalam bentuk lain/teks lain & 80,28 \\
\hline 3 & $\begin{array}{l}\text { Menyajikan pesan sesuai dengan kondisi kehidupan } \\
\text { peserta didik }\end{array}$ & 86,43 \\
\hline 4 & Mendorong kreativitas dalam bersastra & 87,50 \\
\hline \multirow[t]{3}{*}{5} & $\begin{array}{l}\text { Penggunaan diksi, tanda baca, dan bahasa yang baik dan } \\
\text { benar }\end{array}$ & 80,21 \\
\hline & Jumlah Total & 420,07 \\
\hline & Rata-rata & 84,01 \\
\hline
\end{tabular}

Keterangan: memenuhi kelayakan sebagai perancah

Bahan ajar yang dikembangkan dapat memberikan informasi utuh, menginspirasi, dan memotivasi siswa agar dapat mengembangkan kreativitas. Selain itu, bahan ajar yang dikembangkan memiliki tujuan tersirat maupun tersurat terutama dalam pengembangan karakter siswa melalui pesan nilai-nilai moral yang terdapat dalam suatu cerita. Nilai-nilai moral dari cerita rakyat dapat dirancah sebagai pendidikan karakter kepada peserta didik. Dengan demikian bahan ajar yang digunakan dapat menjadi perancah dalam melakukan pendidikan karakter sebagai capaian afeksi siswa, selain pengembangan kognitif dan psikomotorik. Hal ini senada dengan penelitian Ayu, Mulyaningsih, \& Khuzaemah (2021). Dengan 
demikian, selain mata pelajaran Pendidikan Agama dan PPKn sesuai ketentuan Kurikulum 2013, mata pelajaran bahasa Indonesia dapat menjadi perancah pendidikan karakter.

\section{SIMPULAN}

Cerita rakyat yang hidup di lingkungan masyarakat Kabupaten Cirebon memiliki struktur sebagaimana teks sastra pada umumnya sehingga dapat digunakan sebagai bahan ajar di sekolah. Unsur kebahasaan yang digunakan dalam cerita rakyat masih dapat dipahami oleh para siswa sehingga pesan moral dalam cerita rakyat dapat diserap sebagai pendidikan karakter. Bahan ajar yang dikembangkan berdasarkan cerita rakyat yang memiliki kearifan lokal layak digunakan sebagai bahan ajar di SMA, MA, SMK yang menjadikannya sebagai perancah dalam pendidikan karakter. Hal ini berdasarkan hasil validasi dari ahli dan praktisi yang diukur berdasarkan isi, penyajian, bahasa, dan grafika bahan ajar tersebut yang melebihi ketentuan minimal. Berdasarkan hasil uji pakai kepada para siswa secara daring dan para guru diketahui bahwa bahan ajar tersebut memiliki kelayakan untuk digunakan dalam pembelajaran untuk mengembangkan pendidikan karakter melalui kemampuan siswa dalam menulis cerpen dengan menggunakan nilai-nilai moral dari cerita rakyat sebagai ide dasarnya.

\section{DAFTAR PUSTAKA}

Ayu, P. F. A., Mulyaningsih, I., \& Khuzaemah, E. (2021). Analisis Nilai Moral Buku Baban Kana dan Pengembangannya Sebagai Bahan Ajar Cerpen Berbasis Kearifan Lokal. Imajeri: Jurnal Pendidikan Bahasa dan Sastra Indonesia, 3(2), 123-130.

Balitbang. (2010). Panduan Pengembangan Pendidikan Karakter pada Satuan Pendidikan Dasar dan Menengah. Jakarta: Balitbang Kemdikbud.

Berkowitz, M. W., \& Bier, M. C. (2005). What Works in Character Education: A Research-driven Guide for Educators. Washington, DC: Character Education Partnership.

Borg, W.R. \& M. D. Gall. (1983). Educational Research: An Introduction, Fifth Edition. New York: Longman.

Dąbrowska, E. (2019). Experience, Aptitude, and Individual Differences in Linguistic Attainment: A Comparison of Native and Nonnative Speakers. Language Learning. A Journal of Research Language Studies, 69(S1), 72-100. https://doi.org/10.1111/lang.12323.

Danandjaja, J. (1994) Folklor Indonesia. Jakarta: PT Pustaka Utama Grafiti.

Du Toit, C. (2014). Towards a Vocabulary for Visual Analysis: Using Picture

Books to Develop Visual Literacy with Pre-Service Teachers. Mousaion, 32(2), 25-47.

Finnegan, R. (2018). Secrets of the Extraordinary Ordinary: The Revelations of Folklore and Anthropology. Humanities, 7(2), 1-18.

Honig, B. (1985). Last Chance for Our Children: How You Can Help Save Our Schools. Indianapolis: Addison-Wesley Publishing Company.

Kamil, G. (2015). Pembentukan Karakter Melalui Pendidikan Sosiologi. Tingkap, $X I(1), 54-66$.

Kemko Kesra, R. I. (2010). Kebijakan Nasional Pembangunan Karakter Bangsa. Jakarta: Kemko Kesra. 
Kusmana, S. (2014). Kreativitas Menulis. Yogyakarta: Penerbit Ombak.

Kusmana, S., \& Jaja, J. (2019). Study Of Legends And Folklores as Efforts to Develop Instructional Materials in High Schools. International Symposium on Social Sciences, Education, and Humanities (ISSEH 2018), 229-231.

Kusworo, P., \& Hardinto, P. (2009). Efektivitas Penerapan Pendekatan Pembelajaran Scaffolding dalam Ketuntasan Belajar Ekonomi Siswa Kelas X SMA Labortorium Universitas Negeri Malang. Jurnal Pendidikan Ekonomi, 2(1), 74-89.

Liendo, J. G. (2017). Teachers, Folklore, and the Crafting of Serrano Cultural Identity in Peru. Latin American Research Review, 52(3), 378-392. DOI: https://doi.org/10.25222/larr.78.

Mamin, R. (2008). Penerapan Metode Pembelajaran Scaffolding Pada Pokok Bahasan Sistem Periodik Unsur. Chemica: Jurnal Ilmiah Kimia dan Pendidikan Kimia, 9(2), 55-60.

Murray, J., \& Goldbart, J. (2009). Cognitive and Language Acquisition in Typical and Aided Language Learning: A review of Recent Evidence From an Aided Communication Perspective. Child Language Teaching and Therapy, 25(1), 31-58.

Mustari, M. (2011). Nilai Karakter Refleksi Untuk Pendidikan Karakter. Yogyakarta: Laksbang Pressindo.

Narvaez, D. (2002). Does Reading Moral Stories Build Character?. Educational Psychology Review, 14(2), 155-171. DOI: https://doi.org/10.1023/A:101467462 1501

Oring, E. (2008). Legendry and the Rhetoric of Truth. Journal of American Folklore, 121(480), 127-166.

Rokhman, F., Hum, M., Syaifudin, A., \& Yuliati. (2014). Character Education for Golden Generation 2045 (National Character Building for Indonesian Golden Years). Procedia - Social and Behavioral Sciences, 141, 1161-1165. https://doi. org/10.1016/j.sbspro.2014.05.197

Saputro, A. N. (2017). Pengembangan Buku Ajar Menulis Cerita Pendek yang Berorientasi pada Karakter Cinta Tanah Air. Indonesian Language Education and Literature, 2(2), 192-202. DOI: 10.24235/ileal.v2i2.1199.

Sibarani, R. (2012). Kearifan Lokal: Hakikat, Peran, dan Metode Tradisi Lisan. Jakarta: Asosiasi Tradisi Lisan.

Sugiyono, (2010). Metode Penelitian Pendidikan: Pendekatan Kuantitatif, Kualitatif, dan $R \& D$. Bandung: Alfabeta.

Sukmadinata, N. (2010) Metode Penelitian Pendidikan. Bandung: Remaja Rosdakarya dan Program Pascasarjana UPI Bandung.

Suyadi. (2013). Strategi Pembelajaran Pendidikan Karakter. Bandung: PT Remaja Rosdakarya.

Tomlinson, B. (2012). Materials Development for Language Learning and Teaching. Language teaching, 45(2), 143-179. 